\title{
STUDENTS' ENTREPRENEURIAL INTEREST BASED ON ENTREPRENEURSHIP LEARNING MODEL, INDEPENDENT ATTITUDE AND EMOTIONAL INTELLIGENCE: EVIDENCE FROM INDONESIA
}

\author{
Qurnain Nuzulul, Gazali, Lecturers \\ Faculty of Economics, University of Madura, Pamekasan, East Java, Indonesia \\ *E-mail: info@unira.ac.id
}

\begin{abstract}
Higher education is an institution that prepares students to become members of society with academic and professional abilities. Various strategies have been implemented by the government to increase the number of entrepreneurs in Indonesia, one of which is by incorporating entrepreneurship courses into learning learning in higher education. Higher education should give birth to students who have high morale, have critical, creative, innovative and independent thinking to have an entrepreneurial spirit. Data collection was carried out using a questionnaire. The sampling technique uses accidental sampling. The questionnaire was distributed to 362 students in Madura as samples and the data were analyzed using the Structural Equation Model program. The results of this study indicate that the entrepreneurship learning model directly has a significant effect on students' entrepreneurial interest, and the entrepreneurship learning model indirectly has a significant effect on student entrepreneurial interest through independent attitude and emotional intelligence.
\end{abstract}

\section{KEY WORDS}

Entrepreneurship learning model, independent attitude, emotional intelligence, students' entrepreneurial interests.

This research is based on the work ethic of parents or ancestors of the Madurese community in entrepreneurship. Madura community have enthusiasm, are persevering, never give up, like challenges, are independent and have various positive characters that have been inherent in the Madura since time immemorial. One of Madura philosophy mention about hard work and endurance for Madura people. Padded with waves covered in the wind, means that whatever the challenge, how big the obstacle is, it is carried out with courage and patience and fully surrenders life to the Almighty. Based on the observations of researchers with the life of the Madura community today, especially the younger generation who are highly educated or undergraduate after graduating, they look for more jobs (job seekers) than job creators.

To create an students' entrepreneurial interests, it can be started through learning entrepreneurship courses that are taught in higher education, with the Entrepreneurship Learning Model it is expected to be able to create students' entrepreneurial interest, but it will be faster if entrepreneurship course learning begins to be applied in the family, community and institution environment. Meanwhile, internal factors in creating students' entrepreneurial interest are found in the student's personality in the form of an independent attitude and emotional intelligence. In this research, it examines the internal factors of students in creating entrepreneurial interest through the Entrepreneurship Learning Model implemented by universities in Madura, while the external factors in this study are not examined. So, Madurese people basically have the following characteristics and behaviors: entrepreneurship, adventure, hard work, work ethic, efforts that are made by being able to manage emotions and manage time.

This research uses the grand theory of planned behavior which consists of: Attitudes towards behavior, subjective norms and perceptions of behavior control can theoretically be used to predict student interest and behavior towards entrepreneurship. In this research, it is developed and modified by examining: independent attitudes and emotional intelligence in 
mediating the effect of the Entrepreneurship Learning Model on the students' entrepreneurial interests of Madura students who study at four Universities in Madura which will be used as objects in this study because there is still a research gap from some previous research. So Entrepreneurship Learning Model, Independent Attitude And Emotional Intelligence needs to be considered in order to create better students' entrepreneurial interests (Zainurrafiqi and Rachmawati, 2018; Zainurrafiqi, et al (2020). The purpose of this study was to determine the role of Entrepreneurship Learning Model on Independent Attitude and Emotional Intelligence and Its Impact on students' entrepreneurial interests.

\section{THEORETICAL AND HYPOTHESIS REVIEW}

The existence of a good entrepreneurship learning model can shape the mindset, attitudes, and behavior of students to become a true entrepreneur and have a significant effect on students' entrepreneurial interests as a career choice (Ramadhani and Nurnida, 2017; Farouk and Ikram, 2014). While Maryanti et al (2017; Mopangga (2014) states that the Entrepreneurship Learning Model can foster an entrepreneurial spirit in the university environment and has no significant effect on students' entrepreneurial interests. Students in taking Entrepreneurship Learning Model are more dominant in prioritizing graduating with good grades, preferring attendance and no assignments without considering whether or not they have knowledge, rather than fostering the entrepreneurial spirit of these students and low support from parents and family. According to Bygrave (2003:107), students' entrepreneurial interests are not inborn but grow and develop according to the influencing factors. Soemanto (2002:157) states that, the only struggle or way to create human beings who have morals, independent attitudes, and entrepreneurial skills is by learning entrepreneurship. Entrepreneurship learning makes students' insight into more confident, able to choose, and make the right decisions, increase creativity and innovation, foster morals, character, and increase intellectually. Based on the results of previous research, the results of the study of theory and logic of thinking, then the explanation is developed hypotheses:

H1: The entrepreneurial learning model has an effect on students' entrepreneurial interests.

Independent attitude is the desire and behavior of a student who is not easy to depend on others to do his duties and responsibilities. According to Srihasinita (2016; Tshikovhi and Shambare (2015) state that Entrepreneurship Learning Model in a university environment has a significant effect on students' independent attitudes. Opponents et al (2015) stated that the perception and independent attitude towards the Entrepreneurship Learning Model had a good perception even though through the entrepreneurship training learning model, having a negative independent attitude had no significant effect on Entrepreneurship Learning Model. The results of research conducted by Astuti and Mardianty (2012) stated that students' independent attitudes towards students' entrepreneurial interests at the University of Indonesia, North Sumatra University and Andalas University had no significant effect, however at Gajah Mada University, Airlangga University and Hasanudin University, students' independent attitude towards students' entrepreneurial interests has a significant effect. However, the results of research conducted by Rosmiati et al (2015) stated that the independent attitude towards students' entrepreneurial interests had no significant effect. Slameto (2003: 180) states that an independent attitude is something that is learned and how students react to situations and determine what students are looking for in their lives without involving other people. So with this explanation a hypothesis was developed:

H2: Independent attitude mediates the effect of the entrepreneurial learning model on students' entrepreneurial interests.

According to Zakarevicius and Aurimas (2010; Ifham and Helmi (2002) state that learning entrepreneurship courses on emotional intelligence has a significant effect. While Najafi et al (2014) stated that emotional intelligence (self-regulation, motivation and social skills of students) on the learning competence of entrepreneurship courses had no significant effect. The results of research by Paulina and Wardoyo (2012) state that emotional 
intelligence has a significant effect on students' entrepreneurial interests. However, the results of research conducted by Khatoon (2013) stated that there was a significant difference in emotional intelligence on students' entrepreneurial interests. Goleman (1999: 187) states that emotional intelligence is a higher ability that students have in motivating themselves, resilience in the face of failure, controlling emotions and delaying gratification, and regulating mental states. So universities must be able to design Entrepreneurship Learning Model in such a flexible way following the development of the business world and industry to be used as a reference in organizing lectures for students. To create success for students' entrepreneurial interests, it is necessary to develop entrepreneurial-based learning. Based on this explanation, the following hypotheses were developed:

H3: Emotional intelligence mediates the effect of the entrepreneurial learning model on students' entrepreneurial interests.

\section{METHODS OF RESEARCH}

This study explains the role of Entrepreneurship Learning Model on Students Entrepreneurial Interest in University in Madura." The hypothesis testing tool in this study uses SEM (Structural Equation Model) to analyze the relationship between variables. The data used in this research is questionnaire data at universities in Madura consisting of: Trunojoyo Madura University, Madura University, Madura Islamic University and Wiraraja University. The variables in this study were measured by a Likert scale with a range from 1 to 5 where 1 was equal to "Strongly Disagree" and 5 equal to "Strongly Agree". The variables studied consisted of Independent variables, dependent variables and intervening variables. The Independent variable is Entrepreneurship Learning Model which is adopted form Siswoyo, (2009). Intervening variables are Independent Attitude which is adopted form Schwarz et al., (2009) and Emotional Intelligence which is adopted form Goleman, (1999). While the dependent variables are students' entrepreneurial interests are adopted from Mudjiarto and Wahid, (2005). This research includes Explanatory Research (Moh. Herman Djaja, 2021; Nurul Hidayati, 2020; Zainurrafiqi et al., 2021; Zainurrafiqi et al., 2020; Zainurrafiqi and Ria Rachmawati, 2018; Zainurrafiqi, Gazali, and Nuzulul, 2020; Gazali, 2021; Gazali, 2020).

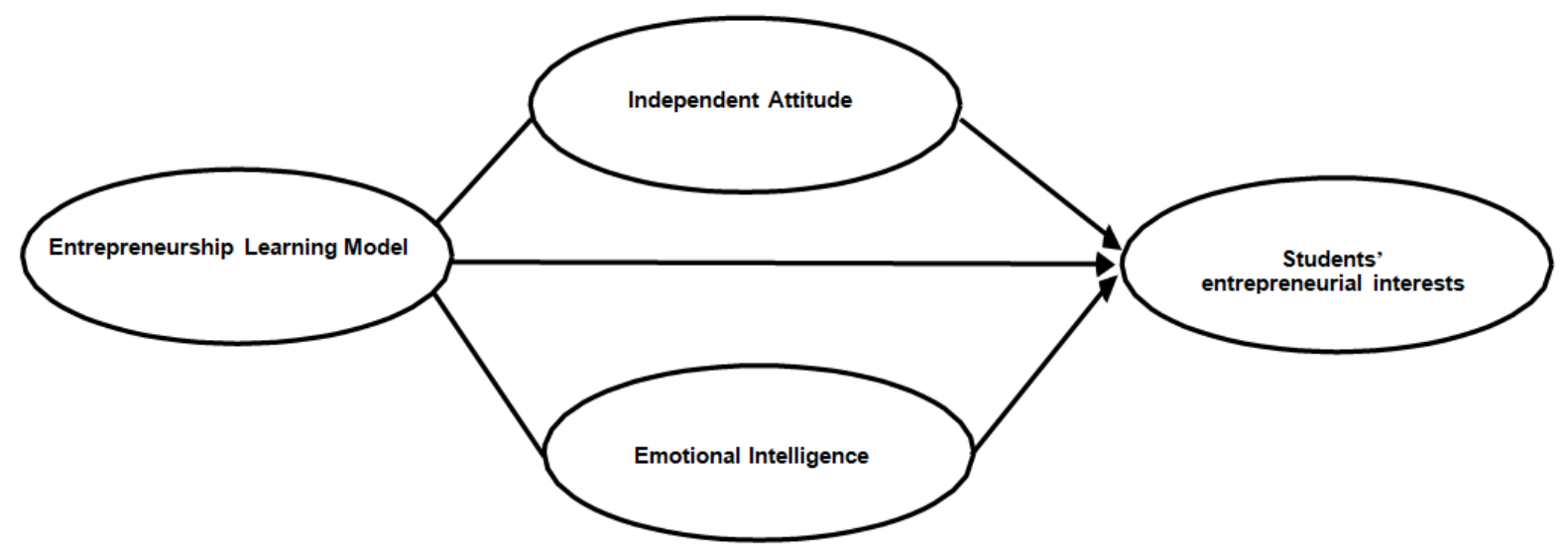

Figure 1 - Research Framework

\section{RESULTS OF STUDY}

The validity test was carried out to test the results of the distribution of the questionnaire to respondents who stated that they were appropriate or valid for the statement items that were compiled as indicators of research variables. The results of testing the validity of 400 respondents with the calculation of the Pearson Product Moment correlation coefficient in table 1 are as follows: 
Table 1 - Validity Test

\begin{tabular}{|c|c|c|c|c|}
\hline Variable & Statement & Coef. Correlation & Sig & Conclusion \\
\hline \multirow{3}{*}{ Entrepreneurship Learning Model (ELM) } & ELM 1 & 0.898 & 0.05 & Valid \\
\hline & ELM 2 & 0.878 & 0.05 & Valid \\
\hline & ELM 3 & 0.894 & 0.05 & Valid \\
\hline \multirow{4}{*}{ Independent Attitude (IA) } & IA 1 & 0.774 & 0.05 & Valid \\
\hline & IA 2 & 0.737 & 0.05 & Valid \\
\hline & IA 3 & 0.839 & 0.05 & Valid \\
\hline & IA 4 & 0.707 & 0.05 & Valid \\
\hline \multirow{5}{*}{ Emotional Intelligence (EI) } & El 1 & 0.863 & 0.05 & Valid \\
\hline & El 2 & 0.721 & 0.05 & Valid \\
\hline & EI 3 & 0.864 & 0.05 & Valid \\
\hline & El 4 & 0.874 & 0.05 & Valid \\
\hline & El 5 & 0.788 & 0.05 & Valid \\
\hline \multirow{4}{*}{ students' entrepreneurial interests (Eln) } & $E \ln 1$ & 0.828 & 0.05 & Valid \\
\hline & Eln 2 & 0.843 & 0.05 & Valid \\
\hline & $E \ln 3$ & 0.811 & 0.05 & Valid \\
\hline & $E \ln 4$ & 0.849 & 0.05 & Valid \\
\hline
\end{tabular}

Source: Data processed (2021).

Based on table 1, it shows that the results of testing the validity of the indicators of all exogenous and endogenous variables are valid, because the correlation coefficient ( $r$ count) between the item score and the total score $\geq 0.05$.

Reliability test is used to determine the reliability or consistency of the instrument (questionnaire) used. The limit value used to assess or to test whether each variable is reliable, reliable and accurate is the Cronbach's Alpha coefficient formula. The variable can be declared reliable if the Cronbach Alpha Coefficient is $\geq 0.60$, meaning that the reliability level of 0.60 is an indication of the reliability of a construct. The following are the results of the reliability testing of 362 respondents as follows:

Table 2 - Reliability Test

\begin{tabular}{llll}
\hline Variable & Cronbach's Alpha & Critical Value & Conclusion \\
\hline Entrepreneurship Learning Model & 0.859 & 0.6 & Reliable \\
Independent Attitude & 0.778 & 0.6 & Reliable \\
Emotional Intelligence & 0.810 & 0.6 & Reliable \\
students' entrepreneurial interests & 0.825 & 0.6 & Reliable \\
\hline
\end{tabular}

Source: Data processed (2021).

Based on table 2, it can be seen that these variables are reliable, because all alpha values are $\geq 0.6$, that all lists of statements (questionnaires) from each variable are reliable. Thus, the list of statements of all variables in the questionnaire is reliable for measuring each variable.

After the SEM assumptions are fulfilled, then the structural feasibility test is carried out and for this several model feasibility indices will be used which can be seen in the results in table 3 as follows:

Table 3 - Evaluation Results Criteria Goodness of Fit Indices

\begin{tabular}{llll}
\hline Criteria & Cut - Off Mark & Result Calculation & Information \\
\hline Chi - Square & Small expected & 483.504 & $\chi^{2}$ with df =176 is less Good \\
Significance Probability & $\geq 0.05$ & 0.000 & less Good \\
RMSEA & $\leq 0.08$ & 0.070 & Good \\
GFI & $\geq 0.90$ & 0.895 & Good \\
AGFI & $\geq 0.90$ & 0.862 & Pretty good \\
CMIN/DF & $\leq 2.00$ & 2.747 & Pretty good \\
TLI & $\geq 0.90$ & 0.918 & Good \\
CFI & $\geq 0.90$ & 0.932 & Good \\
\hline
\end{tabular}

Source: Data processed (2021). 
Based on table 3, it can be explained that the results of the goodness of fit test on the structural equation model above show a probability value of 0.000 , which means $\geq 0.05$ in the unfavorable category. According to Hair et al (1988), the model is said to be feasible if at least one of the model's feasibility test methods is met, if the model's feasibility test can meet more than 1 eligibility criteria, the confirmatory analysis model will be much better than only 1 being met. According to Byrne (2001) states that in testing Structural Equation Modeling (SEM) there are two approaches: statistical measures through chi-square and goodness of fit index, if one approach is met then the model can be accepted so that the analysis can be continued because it has met the required criteria.

The results of the research hypothesis test were carried out based on the results of the analysis of the causality relationship between the research constructs, which are presented in table 4 as follows:

Table 4 - Research Hypothesis Test Results

\begin{tabular}{|c|c|c|c|c|c|}
\hline Variable & Coefficient & S.E & $\mathrm{CR}$ & Prob. & Decision \\
\hline Entrepreneurship Learning Model $\rightarrow$ & 0.385 & 0.119 & 2.738 & 0.006 & Significant \\
\hline \multicolumn{6}{|l|}{ students' entrepreneurial interests } \\
\hline Entrepreneurship Learning Model $\rightarrow$ & 0.780 & 0.054 & 12.655 & 0.000 & \multirow[b]{2}{*}{ Significant } \\
\hline $\begin{array}{l}\text { Independent Attitude) } \rightarrow \text { students' } \\
\text { entrepreneurial interests }\end{array}$ & 0.291 & 0.070 & 4.019 & 0.000 & \\
\hline \multirow{2}{*}{$\begin{array}{l}\text { Entrepreneurship Learning } \\
\text { Emotional Intelligence } \rightarrow \\
\text { entrepreneurial interests }\end{array}$} & 0.792 & 0.061 & 13.641 & 0.000 & \multirow[b]{2}{*}{ Significant } \\
\hline & 0.150 & 0.058 & 2.082 & 0.037 & \\
\hline
\end{tabular}

Source: Data processed (2021).

The effect of the learning model for entrepreneurship courses on students' entrepreneurial interest in this research can be seen in Figure 2 hypothesis testing as follows:

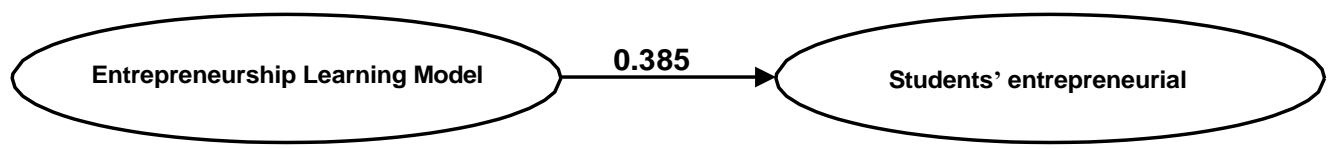

Figure 2 - Entrepreneurship Learning Model Influences Students' Entrepreneurial Interest

Seen in Table 4 and Figure 2, the results of the analysis on the path coefficient of the variable effect of Entrepreneurship Learning Model on students' entrepreneurial interest obtained a coefficient value of 0.385 with CR 2.738 and a p-value of 0.006 . The $p$-value is $\leq$ 0.05 , so the hypothesis is accepted that the Entrepreneurship Learning Model has a significant effect on students' entrepreneurial interest with a positive coefficient which indicates that the higher the value of the Entrepreneurship Learning Model will affect the higher students' entrepreneurial interests.

To answer hypotheses two and three through the Sobel test with the following results:

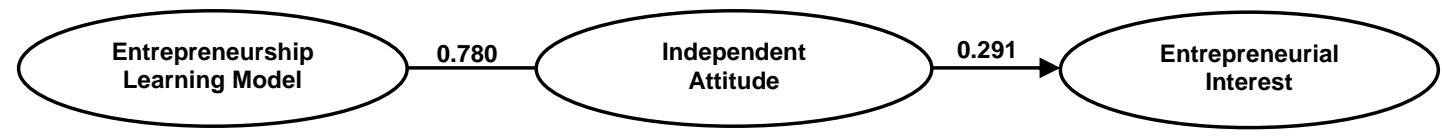

Figure 3 - Independent Attitudes Mediating the Influence of Entrepreneurship Learning Model on Students' Entrepreneurial interest 
Figure 3 show that the independent attitude mediates the effect of Entrepreneurship Learning Model on students' entrepreneurial interest. With the results of the Sobel test independent attitude as follows:

Table 5 - Independent Attitude Sobel Test Results

\begin{tabular}{llllll}
\hline & Input: & & Test Statistic & Std. Error & $p$-value \\
\hline$a$ & 0.780 & Sobel Test & 3.99498164 & 0.05681628 & 0.0000647 \\
$b$ & 0.291 & Arion Test & 3.98616945 & 0.05694188 & 0.00006715 \\
sa & 0.054 & Godman test & 4.00385254 & 0.0566904 & 0.00006232 \\
sb & 0.070 & Reset all & & Calculate & \\
\hline
\end{tabular}

Source: Data processed (2021).

Based on the results of the Sobel test in table 5 to analyze independent attitudes to mediate the significant effect of Entrepreneurship Learning Model on student entrepreneurial interest, the Sobel test score is 3.99498164 above 1.96, and then hypothesis is accepted.

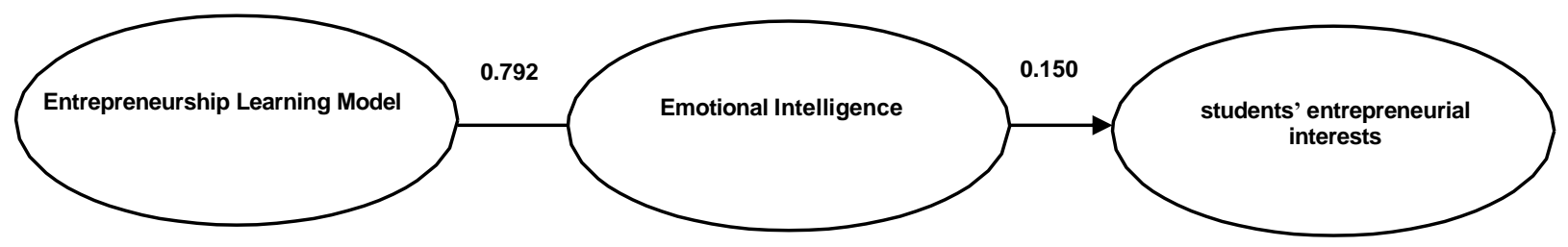

Figure 4 - Emotional Intelligence Mediates the Influence of Entrepreneurship Learning Model on Students' Entrepreneurial Interest

Figure 4 show that emotional intelligence mediates the effect of Entrepreneurship Learning Model on students' entrepreneurial interest. With the results of the Sobel test of emotional intelligence as follows:

Table 6 - Results of the Sobel Test Emotional Intelligence

\begin{tabular}{|c|c|c|c|c|c|}
\hline & Input: & & Test Statistic & Std. Error & $p$-value \\
\hline$a$ & 0.792 & Sobel Test & 2.53637874 & 0.04683843 & 0.01120055 \\
\hline$b$ & 0.150 & Arion Test & 2.52917362 & 0.04697186 & 0.01143315 \\
\hline sa & 0.061 & Godman test & 2.5436458 & 0.04670462 & 0.01097023 \\
\hline$s b$ & 0.058 & Reset all & & Calculate & \\
\hline
\end{tabular}

Source: Research data (processed).

Based on the results of the Sobel test in table 6 to analyze emotional intelligence to mediate the significant effect of Entrepreneurship Learning Model on students' entrepreneurial interest, the Sobel test score is 2.53637874 above 1.96 , and then hypothesis is accepted.

Table 7 - Result of Total Influence between Variables

\begin{tabular}{|c|c|c|c|}
\hline Influence Between Variables & Coefficient & Influence Coefficient Between Variables & Information \\
\hline$\overline{E L M}>>I A->$ Eln & $E L M->I A=0.780 \quad I A->E I n=0.291$ & 0.227 & Significant \\
\hline ELM -> El -> Eln & $E L M->E I=0.792 \quad E I->E I n=0.150$ & 0.119 & Significant \\
\hline Total & & 0.356 & \\
\hline
\end{tabular}

Source: Data processed (2021). follows:

Based on table 7, the results of the total effect between variables can be explained as

1. In table 7 where the results of the analysis on the path coefficient through the independent attitude variable are 0.227. The effect of Entrepreneurship Learning Model on independent attitudes is 0.780 , and the independent attitude towards students 'entrepreneurial interests is 0.291 , both of which are significant, so it can be 
concluded that the hypothesis is accepted, there is a significant influence on the independent attitude mediating the Entrepreneurship Learning Model on students' entrepreneurial interests. So in the independent attitude which has a significant effect the highest value of the results of the total effect between variables is 0.227 . It shows that the most dominant student independent attitude consisting of students is able to compete, is able to manage finances, is able to follow changes and has a high willingness to develop entrepreneurship;

2. In table 7 where the results of the analysis on the path coefficient through the emotional intelligence variable are 0.119 . The effect of Entrepreneurship Learning Model on emotional intelligence is 0.792 , and emotional intelligence on students' entrepreneurial interest is 0.150 , both of which are significant, so it can be concluded that the hypothesis is accepted that there is a significant effect of emotional intelligence mediating the Entrepreneurship Learning Model on students' entrepreneurial interest.

\section{DISCUSSION OF RESULTS}

The results of the hypothesis testing conducted show that the Entrepreneurship Learning Model has a significant effect on students' entrepreneurial interests at the University of Madura, meaning that the two variables between the Entrepreneurship Learning Model on students' entrepreneurial interests have a positive relationship, so it can be said that the better the Entrepreneurship Learning Model, the better the students' entrepreneurial interests in University students in Madura will be. Likewise, on the other hand, the less good the Entrepreneurship Learning Model, the less good the students' entrepreneurial interests in Madura university will be. That it is very important to pay attention to the learning model for Entrepreneurship Learning Model that are adjusted to the conditions of University students in Madura which is perceived to have a positive influence on students' entrepreneurial interests. These results are supported by previous research, namely: Wu and Wu (2008), stated that with a good entrepreneurship learning model students are able to actualize themselves with an interest in entrepreneurship to earn profits and want to be free in managing business management. Supported by theories from: Kasali (2010:30), Slameto (2003:87), Suryana (2008:123), Kautonen et al (2008:195), That the learning model of entrepreneurship courses used in the learning process must vary between theory and practice of entrepreneurship to avoid boredom and boredom in students by focusing on entrepreneurship practices which have an impact on increasing students' entrepreneurial interests. To achieve this goal, it is necessary to have support from all stakeholders, both the University in Madura, and parents of students.

The results of the hypothesis testing conducted show that the independent attitude is able to mediate the significant influence of the Entrepreneurship Learning Model on students' entrepreneurial interest, meaning that the Entrepreneurship Learning Model has a positive relationship with the students' entrepreneurial interests through this independent attitude, with this the Entrepreneurship Learning Model has a positive relationship with independent attitudes, while independent attitudes have a positive relationship with students' entrepreneurial interest. Supported by previous researchers: Bagheri and Pihie (2009), and Arasti et al (2012), states that with the Entrepreneurship Learning Modelthat is applied appropriately, it is able to create an independent attitude of students even though there is no one learning model that is suitable for all students.

The results of the hypothesis testing conducted show that the emotional intelligence of students mediates the significant influence of the Entrepreneurship Learning Model on students' entrepreneurial interests, meaning that the Entrepreneurship Learning Model has a positive relationship with the students' entrepreneurial interests through emotional intelligence, the Entrepreneurship Learning Model has positive relationship to emotional intelligence, while emotional intelligence has a positive relationship with students' entrepreneurial interests. Supported by previous research by Bagheri and Pihie (2009; Wardoyo (2010) and Wijaya and Tony (2007), students who are emotionally intelligent are 
more likely to succeed than intellectually intelligent individuals, but are less emotionally intelligent. Students, who have a higher level of emotional intelligence, can have a higher feeling of success in entrepreneurial interests. Supported by the theory of Chandra (2001:89; Saphiro and Lawrence (2008:221; and Sobur (2003:85) stated that students who really optimize their emotional intelligence will be more observant in seeing an opportunity and will be more agile in acting and have more initiative. So students will be better prepared to see opportunities, business negotiations, better able to carry out business strategies, have sensitivity, creativity, high commitment and also reveal that $80 \%$ of students' success in entrepreneurship is determined by their emotional intelligence.

\section{CONCLUSION}

The conclusion of this study is that the results of this study indicate that entrepreneurship learning model has a positive effect on students' interest in entrepreneurship. The entrepreneurship learning model has a positive effect on students' entrepreneurship interest through an independent attitude, and the entrepreneurship learning model has a positive effect on students' entrepreneurship interest through emotional intelligence.

Universities in Madura should be expected to learn more about entrepreneurship learning models rather than theoretical ones and increase the form of cooperation with companies that can be used as partners for practice and comparative study of students in increasing interest in entrepreneurship to create awareness of the benefits and importance of entrepreneurship. It is hoped that students both at college and after graduating from Strata are able to start entrepreneurship, and for further research it is hoped that they can use other independent variables that are thought to affect the entrepreneurial interest of University students in Madura so that more complete information will be obtained on the factors involved can influence students in entrepreneurship positively.

\section{REFERENCES}

1. Boldureanu, G., A.M. Ionesco. A.M. Bercu. M.V.B. Grigoruta. dan D. Boldureanu. 2020. Entrepreneurship Education through Successful Entrepreneurial Models in Higher Education Institutions.

2. Byrne, B.M. 2001. Structural Equation Modeling with AMOS, EQS, and LISREL: Comparative Approaches to Testing for the Factorial Validity of a Measuring Instrument. International Journal of Testing 1(1) 55-86.

3. Chen, H.X., X. Xuemei. dan P. Philips. 2019. Emotional intelligence and conflict management styles. International Journal of Organizational Analysis 27(3) 458 - 470.

4. Costa, F.D., A.A.C. Soares, D.G. Bonfim. 2009. Factors of Influence on the Entrepreneurial Interest: an Analysis with Students of Information Technology Related Courses. Journal of Information System and Technology Management 6(2) $227-246$.

5. Gazali (2019). Work Ethics of Madura Communities in Salt Business: A Case Study Indonesian. International Research Association for Talent Development and Excellence. Vol.12, No.1, pp. 3537-3549

6. Gazali (2021). Employee Performance and Compensation: Evidence from Indonesia. Journal of Management Information and Decision Sciences, Vol 24, Special Issue 6, pp 1-12.

7. Goleman, D. 1999. Working with Emotional Intelegence. Bantam Doubleday Dell Publishing Group Inc. New York. Terjemahan A. Widodo. 2001. Kecerdasan Emosi untuk Mencapai Puncak Prestasi. Edisi Kedua. Gramedia Pustaka Utama. Jakarta.

8. Hair, J.F.J., R.E. Anderson., R.L. Tatham. And W.C Black. 1998. Multivariate Data Analysis. 5th edn, Prentice Hall. Upper Saddle River. New Jersey.

9. Ilahi, S, and M. Ahmed. 2016. Perception and Attitude of Employees of Telecommunication Sector towards the Organization. Asian Journal of Management Applications and Research 7(1) 12-25. 
10. Joyce B.R. dan M. Wiel. 1996. Models of Teaching. Fifth Edition. Prentice-Hall Publications Inc. New Jersey.

11. Moh. Herman Djaja dan Zainurrafiqi (2021). Pengaruh Kepemimpinan Transformasional Terhadap Kinerja Karyawan Dengan Motivasi Kerja Sebagai Variabel Intervening (Survey pada Karyawan PT. Marinal Indoprima Sumenep), Assyarikah: Journal of Islamic Economic Business FEBI Institut Dirosat Islamiyah Al-Amien Prenduan, Vol. 2 No.1 pp. $01-16$.

12. Nurul Hidayati dan Zainurrafiqi (2020). Empirical Study of Customer Satisfaction and Customer Loyalty: The role of Innovation Capability and Ethical Behavior, Assyarikah: Journal Of Islamic Economic Business FEBI Institut Dirosat Islamiyah Al-Amien Prenduan, Vol. 1 No. 1 pp. 1 - 20.

13. Oskade, U.A., A.O. Lawanson, D.A. Sobowale. 2017. Entrepreneurial Interest and Academic Performance in Negeria: Evidence from Undergraduate Students in the University of Ibadan. Journal of Innovation and Entrepreneurship 6(9) 1 - 15.

14. Oviatt, B.M. dan P.P. McDougall. 2005. Defining International Entrepreneurship and Modeling the Speed of Internationalization. Journal of Entrepreneurship Theory and Practice 29(5): 537-554.

15. Packham, G., P. Jones., C. Miller., D. Pickernell, dan B. Thomas. 2010. Attitudes towards entrepreneurship education: a comparative analysis. Journal Education dan Training 52(8): 568-586.

16. Zainurrafiqi , Ria Racawati, Devi Lestari Pramita Putri , Enza Resdiana , Endang Widyastuti , Qaiyim Asy'ari , Rusdiyanto, W. H (2020). The Determinants And Consequents Of Competitive Advantage Based Of Local Wisdom At The Micro, Small, And Medium Enterprise: Evidence From Indonesia. Solid State Technology, 63(6), 1604-1620. http://solidstatetechnology.us/index.php/JSST/article/view/2260

17. Zainurrafiqi and Ria Rachmawati (2018). Pengaruh Etika Bisnis, Faktor Kontingensi Dan Tingkat Penggunaan Internet Terhadap Daya Saing. Ekuitas: Jurnal Ekonomi Dan Keuangan, 2(4), 550-571. https://doi.org/10.24034/j25485024.y2018.v2.i4.426

18. Zainurrafiqi., Gazali, N. Qurnain. and Nurul H. 2020. The Effect of Organization Learning Capability and Organizational Innovation on Competitive Advantage and Business Performance. Russian Journal of Agricultural and Socio-Economic Sciences. 3 (99) 9-17.

19. Zainurrafiqi., Siti, Salama Amar., Rohmaniyah., Rini, Aristin., R.P.Much, Muchtar., Rusnani., Miftahol, Arifin., Abdul, Hadi., Kusik, Kusuma Bangsa., Nurul, Hidayati (2021).The Effect of Utilitarian Value and Hedonic Value on Customer Loyalty with Customer Satisfaction As an Intervening Variable: Empirical Evidence from Indonesia, International Journal of Multicultural and Multireligious Understanding (IJMMU), Vol. 8, No. 5, pp 291-305.

20. Zydziunaite, V., M. Tereseviciene. dan G. Gedviliene. 2014. The Structure of Independent Learning in Higher Education: Students' Attitude. Proceeding of the International Scientific Conference 1(1) 336-334. 